\title{
ON THE INHIBITORY MECHANISM OF BASSIANOLIDE, A CYCLODEPSIPEPTIDE, IN ACETYLCHOLINE-INDUCED CONTRACTION IN GUINEA-PIG TAENIA COLI
}

\author{
Shinjiro NAKAJYO, Kazumasa SHIMIZU and Atsuko KOMETANI \\ Department of Veterinary Pharmacology, Nippon Veterinary and Zootechnical College. \\ Musashino. Tokyo 180, Japan \\ Akinori SUZUKI \\ Department of Agricultural Chemistry, Faculty of Agriculture, \\ University of Tokyo, Bunkyo-ku. Tokyo 113, Japan \\ Hiroshi OZAKI and Norimoto URAKAWA \\ Department of Veterinary Pharmacology. Faculty of Agriculture, \\ University of Tokyo. Bunkyo-ku. Tokyo 113, Japan
}

Accepted January 20, 1983

\begin{abstract}
The effect of bassianolide (BASS), a cyclodepsipeptide, was investigated on mechanical response, membrane potential, intracellular $\mathrm{Na}$ and $\mathrm{K}$ contents and ${ }^{45} \mathrm{Ca}$ uptake in response to acetylcholine $(A C h)$ in guinea-pig taenia coli. BASS $\left(10^{-5} \mathrm{M}\right)$ as well as verapamil $\left(5 \times 10^{-7} \mathrm{M}\right)$ and papaverine $\left(3 \times 10^{-5} \mathrm{M}\right)$ selectively inhibited the tonic component of the contraction induced by ACh $\left(10^{-5} \mathrm{M}\right)$, but scarcely affected the phasic one. In contrast, atropine $\left(3 \times 10^{-8} \mathrm{M}\right)$ inhibited both components of contraction. BASS did not modify the change in membrane potential by ACh. BASS, ACh and the combination of both did not influence the intracellular $\mathrm{Na}$ and $\mathrm{K}$ contents and the ${ }^{45} \mathrm{Ca}$ uptake. These data show that BASS seems unlikely to have the property of an ionophore. BASS slightly inhibited both the tonic and phasic components of contraction induced by $60 \mathrm{mM} \mathrm{K}$ in a non-selective manner, though verapamil and papaverine inhibited the tonic component more potently than the phasic one. Verapamil decreased the increased ${ }^{45} \mathrm{Ca}$ uptake in the muscle soaked in $60 \mathrm{mM} \mathrm{K}$ medium, but BASS did not. Since BASS selectively inhibits the tonic component of the ACh-induced contraction, the inhibitory mechanism of BASS seems to be different from that of verapamil, papaverine or atropine: and the mechanism may be beyond the interactions with a binding activity of ACh to the muscarinic receptor. membrane potential and the contractile machinery of the intestinal smooth muscle.
\end{abstract}

Bassianolide (BASS) is a cyclodepsipeptide isolated from the cultured mycelia of Beauveria bassiana, a pathogenic organism to the silk worm (1, 2). Nakajyo et al. (3) have reported that BASS inhibits the isotonic contractions induced by cholinergic drugs, histamine, 5-hydroxytryptamine and prostaglandin $E_{2}$; but it slightly inhibits the contraction induced by barium ( $\mathrm{Ba}$ ) or high concentration of potassium (high $\mathrm{K}$ ) in the ileal longitudinal muscle preparation of guinea-pig. Moreover, BASS inhibited the contractions induced by adrenergic and cholinergic drugs and histamine, though it hardly influenced the contraction by $\mathrm{Ba}$ or high $K$ in guinea-pig vas deferens (3). On the other hand. Nakajyo et al. (4) have shown that BASS inhibited the contraction 
by high $\mathrm{K}$, Ba or tetraethylammonium as well as adrenergic drugs in guinea-pig aorta. They have suggested that BASS inhibits the contractile actions of drugs which have an effect upon a selective site or receptor of the smooth muscle cell in the ileum and the vas deferens, except for guinea-pig aorta.

Although BASS inhibited the contraction induced by $\mathrm{ACh}$ in the ileal longitudinal muscle or vas deferens of guinea-pig. BASS did not affect a witch stimulated by electric shock in a mouse phrenic nerve-diaphragm muscle preparation and in a frog sciatic nerve-sartorius muscle preparation. BASS also had no effect on the ACh-induced contracture in a frog rectus abdominis preparation (5). They have suggested that BASS depresses the muscarinic response to $\mathrm{ACh}$, but not the nicotinic $\left(\mathrm{N}_{2}\right)$ one. Furthermore, BASS did not affect the binding activity of [3- $\left.{ }^{3} \mathrm{H}\right]$ quinuclidinil benzylate $\left({ }^{3} \mathrm{H}-\mathrm{QNB}\right)$ to the muscarinic receptor of the crude synaptosomal membrane preparation of the cerebral cortex of guinea-pig or mouse. Accordingly, the inhibitory action of BASS on the muscarinic response in smooth muscle. unlike atropine, may not be due to an inhibition of ACh binding to the receptor (5).

In the present study, we investigated the effect of BASS on changes by $\mathrm{ACh}$ in the mechanical response, membrane potential, intracellular $\mathrm{Na}$ or $\mathrm{K}$ contents and ${ }^{45} \mathrm{Ca}$ uptake in guinea-pig taenia coli. Moreover, the experiment was performed to compare the effect of BASS with that of verapamil, papaverine or atropine, which is a typical relaxant in intestinal smooth muscles. The results showed that BASS selectively inhibited the ACh-induced tonic contraction. though it slightly inhibited both the tonic and phasic components of the $60 \mathrm{mM} \mathrm{K}$-induced contraction.

\section{Materials and Methods}

Measurement of mechanical and electrical responses: Male guinea-pigs weighing $400-$ $500 \mathrm{~g}$ were killed by a blow on the head and bled to death. Smooth muscle strips of taenia coli, approximately $15 \mathrm{~mm}$ long in situ. were removed. The muscle preparation was suspended in a modified Tyrode solution exposed to a gas mixture of $95 \% \mathrm{O}_{2}$ and $5 \%$ $\mathrm{CO}_{2}$. The composition of the solution (mM) was $\mathrm{NaCl}, 136.8: \mathrm{KCl}, 5.4: \mathrm{CaCl}_{2}, 2.5$; $\mathrm{MgCl}_{2}, 1.0: \mathrm{NaHCO}_{3}, 11.9$ and glucose, 5.5. The organ bath was kept at $36 \pm 1{ }^{\circ} \mathrm{C}$ and $\mathrm{pH}$ 7.2. The muscle strip was attached to the arm of a force displacement transducer (Nihon Kohden). After the equilibration of the muscle in the normal solution for $30 \mathrm{~min}$, the resting tension was adjusted to $0.5 \mathrm{~g}$. The contractile tension of the muscle strip was recorded isometrically. Then an appropriate volume of $1 \mathrm{M} \mathrm{KCl}$ solution was added hypertonically to the organ bath to give a final concentration of 40 or $60 \mathrm{mM} \mathrm{K}$. The maximal size of the muscle contraction induced by an agonist was regarded as $100 \%$. Since the effect of a 15 min exposure to BASS proved to be optimal, antagonists or BASS were applied 15 min before the application of agonists. unless otherwise stated.

The membrane potential was measured by extracellular recording using the single sucrose gap method as described by Bülbring and Burnstock (6).

Determination of $\mathrm{Na}$ and $\mathrm{K}$ contents: For estimates of cellular $\mathrm{Na}$ and $\mathrm{K}$ contents, the "La method", developed by van Breemen (7). was employed. To be consistent with the contraction experiments, tissues were pretreated with antagonist for $15 \mathrm{~min}$ before exposing them to either $\mathrm{ACh}\left(10^{-5} \mathrm{M}\right)$ or high $\mathrm{K}$ solution also containing antagonist. After incubation of the muscle strips in various test solutions, the strips were then transferred to a La-sucrose solution containing isotonic sucrose and $1 \mathrm{mM} \mathrm{LaCl}_{3}$. at $0.5^{\circ} \mathrm{C}$. After the La treatment for $30 \mathrm{~min}$. each of the strips was blotted between filter 
papers and weighed. It was then ashed in a quartz tube with $0.5 \mathrm{ml}$ of a mixture of equal amounts of $\mathrm{HNO}_{3}(61 \%)$ and $\mathrm{HClO}_{4}(60 \%)$, overnight at $180^{\circ} \mathrm{C}$. The samples were then redissolved in $0.01 \mathrm{~N} \mathrm{HCl}$ solution. $\mathrm{Na}$ and $K$ contents in the samples were measured by flame photometry and expressed as $\mathrm{mmol} / \mathrm{kg}$ wet $w$ t. of this tissue. Since the La wash removed a $\mathrm{Na}$ fraction bound to the cell membrane surface, the value of cellular $\mathrm{Na}$ content in this paper was lower than a value obtained from the total tissue $\mathrm{Na}$ content substracting $\mathrm{Na}$ content in the extracellular space.

Experiment of ${ }^{45} \mathrm{Ca}$ uptake: ${ }^{45} \mathrm{Ca}$ uptake into the smooth muscle cells was measured by a modified "La method" which was developed by Karaki and Weiss (8). In an experiment to study the rate of $\mathrm{Ca}$ uptake. the tissues which had been incubated in normal medium containing $2.5 \mathrm{mM} \mathrm{Ca}$ for $2 \mathrm{hr}$, were exposed to solutions containing ${ }^{45} \mathrm{Ca}$ for short periods of time, 3 or $6 \mathrm{~min}$. The amount of ${ }^{45} \mathrm{Ca}$ entering the tissue during a short period can be assumed to be primarily due to $\mathrm{Ca}$ influx (9). The time schedule of incubation in the various test solutions was almost the same as that used in the experiment for "Determination of $\mathrm{Na}$ and K contents". After incubation with various test solutions labelled with ${ }^{45} \mathrm{Ca}(5 \mu \mathrm{Ci} / \mathrm{ml}$, New England Nuclear), the muscle strips were exposed to the $\mathrm{La}$ solution $\left(\mathrm{LaCl}_{3}\right.$. $73.8 \mathrm{mM}$; glucose, $5.5 \mathrm{mM}$ and Tris- $\mathrm{HCl}$. $11.9 \mathrm{mM}$ ) at $0.5^{\circ} \mathrm{C}$ for $60 \mathrm{~min}$. The strips were then placed in scintillation vials containing $0.5 \mathrm{ml}$ of tissue solubilizer (Soluene350. Packard) and were digested by warming overnight at $55^{\circ} \mathrm{C}$. The sample was then mixed with $5 \mathrm{ml}$ of dioxane based scintillator, and radioactivity was determined using a liquid scintillation spectrometer (Tri-Carb 3380. Packard). Intracellular ${ }^{45} \mathrm{Ca}$ content was expressed as $\mu \mathrm{mol} / \mathrm{kg}$ tissue.

Drugs used: BASS isolated from the cultured fungi Beauveria bassiana is a cyclodepsipeptide composed of four molecules of $1-N$-methylleucine and $d-\alpha$ hydroxy-isovaleric acid. The molecular formula is $\left(\mathrm{C}_{12} \mathrm{H}_{21} \mathrm{NO}_{3}\right)_{4}$ and its molecular weight is 908 . It is a white crystalline substance which is insoluble in water and soluble in organic solvents. BASS was dissolved in ethanol at the desired concentration, and the ethanol solution was applied in a volume of less than $0.02 \mathrm{ml}$ in the $15 \mathrm{ml}$ organ bath solution. The same volume of ethanol was applied as a control to confirm that ethanol itself had no influence upon the preparation in any of the types of experiments. The following drugs were used: acetylcholine chloride (ACh, Daiichi Seiyaku), atropine sulphate (ATR, Wako Junyaku), verapamil (Eisai) and papaverine hydrochloride (Daiichi Seiyaku).

The results are presented as the mean values \pm S.E.M. for $n$ experiments. Differences were analyzed using the Student's $t$-test to determine significant differences.

\section{Results}

Effect of BASS on ACh-induced contraction: An application of $10^{-6} \mathrm{M} \mathrm{ACh}$ induced a phasic contraction $(6 \mathrm{~g})$ followed by a tonic one $(4 \mathrm{~g})$ in spontaneously active smooth muscles of guinea-pig taenia coli. $\mathrm{ACh}$ at higher concentrations $\left(10^{-5}-10^{-4} \mathrm{M}\right)$ enhanced both the contractile responses. The typical responses of the six muscle strips to ACh $\left(10^{-5} \mathrm{M}\right)$ are shown in Fig. 1A \& B. A pretreatment with $5 \times 10^{-7} \mathrm{M}$ verapamil for $15 \mathrm{~min}$ depressed the spontaneous contractions in amplitude and frequency and inhibited $25-30 \%$ of the phasic response to ACh ranging from $10^{-6}$ to $10^{-4} \mathrm{M}$, while it inhibited almost completely the tonic response to $10^{-6} \mathrm{M}$ and $10^{-5} \mathrm{M} \mathrm{ACh}$, but $7 \%$ of the tonic response remained at $10^{-5} \mathrm{M}$ ACh (Figs. $1 \mathrm{~A} \& 2)$. Papaverine $\left(3 \times 10^{-5} \mathrm{M}\right)$ exhibited similar results to verapamil as 


\section{$60 \mathrm{~K}$}

$\boldsymbol{A}$

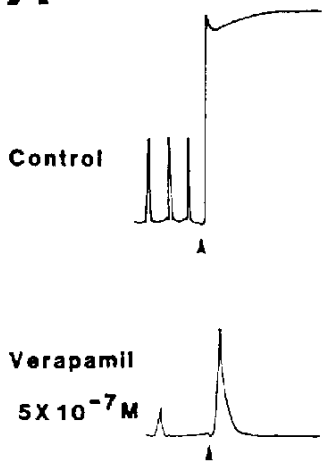

B

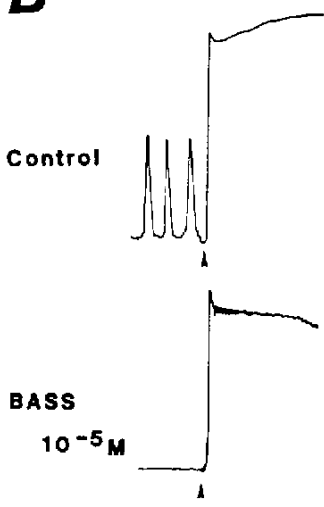

$\mathrm{ACH}$

$10^{-5} \mathrm{M}$
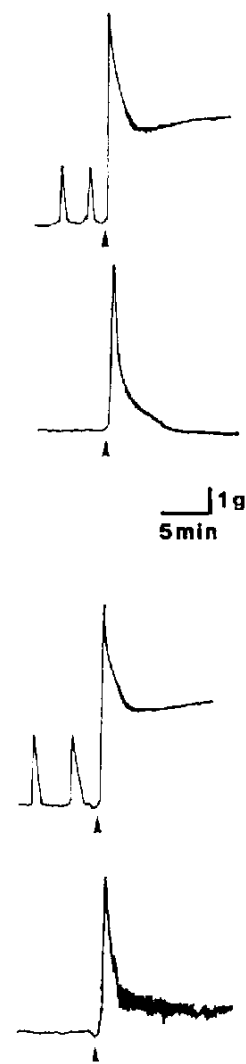

Fig. 1. Effect of verapamil $\left(5 \times 10^{-7} \mathrm{M}\right)(\mathrm{A})$ and bassianolide (BASS, $10^{-5} \mathrm{M}$ ) (B) on a contraction induced by acetylcholine $\left(10^{-5} \mathrm{M}\right)$ or $60 \mathrm{mM} \mathrm{K}$ in guinea-pig taenia coli. All drugs were pretreated $15 \mathrm{~min}$ before the application of acetylcholine or $60 \mathrm{mM} \mathrm{K}$ in each muscle strip.

shown in Fig. 2. When the muscle was pretreated with $3 \times 10^{-8} \mathrm{M}$ atropine, the antagonist slightly affected the spontaneous activity, but completely blocked both the tonic and phasic components of contraction induced by $10^{-6} \mathrm{M} \mathrm{ACh}$. However, increasing ACh concentration gradedly developed tensions of both the components in the presence of atropine which shows a competitive antagonism (Fig. 2). On the other hand, the phasic response to $10^{-6}$ to $10^{-4} \mathrm{M}$ ACh was not significantly depressed by a

pretreatment with $10^{-6} \mathrm{M}$ BASS for $15 \mathrm{~min}$, but the tonic responses to $\mathrm{ACh}$ at the three concentrations were inhibited to $80 \%$. These data are not shown in the figure. Further, $10^{-5} \mathrm{M}$ BASS inhibited the spontaneous activity and $28 \%, 17 \%$ or $16 \%$ of the phasic response to $10^{-6} \mathrm{M} \cdot 10^{-5} \mathrm{M}$ or $10^{-4} \mathrm{M} \mathrm{ACh}$, respectively. BASS $\left(10^{-5} \mathrm{M}\right)$ also inhibited $96 \%, 88 \%$ or $76 \%$ of the tonic response by $10^{-6} \mathrm{M} \cdot 10^{-5} \mathrm{M}$ or $10^{-4} \mathrm{M} \mathrm{ACh}$, respectively (Figs. $1 \mathrm{~B} \& 2$ ). An exposure to $10^{-6} \mathrm{M}$ BASS for $60 \mathrm{~min}$ or to $10^{-5} \mathrm{M}$ BASS for $30 \mathrm{~min}$ did not increase the inhibitory effects on the $\mathrm{ACh}$ induced contraction.

In another series of experiments, a transient contraction by an application of $60 \mathrm{mM} \mathrm{K}$ showed approximately $8 \mathrm{~g}$ of tension followed by a tonic one of almost the same size. The phasic component was inhibited to $50 \%$ by the pretreatment with $5 \times 10^{-7} \mathrm{M}$ verapamil for $15 \mathrm{~min}$, and the tonic one was completely inhibited (Figs. 1A \& 2). Since papaverine at a concentration of $3 \times 10^{-5} \mathrm{M}$ inhibited the phasic component of the high $K$-induced contraction to $44 \%$ and the tonic one to $9 \%$, papaverine as well as verapamil may selectively inhibit the tonic contraction of the muscle in high $\mathrm{K}$ medium. Although atropine slightly depressed the phasic contraction, it did not affect the tonic one (Fig. 2). Atropine which selectively inhibits the ACh binding to the muscarinic receptor did not inhibit both the phasic and tonic components of the high K-induced contraction (Fig. 2). After the pretreatment with BASS at a concentration of $10^{-6} \mathrm{M}$ or $10^{-5} \mathrm{M}$ for 15 or $30 \mathrm{~min}$. BASS inhibited $20 \%$ of both the phasic and tonic components in the high K-induced contraction: BASS inhibited somewhat both the phasic and tonic components to the same extent, in a different manner from verapamil and papaverine (Figs. 1B \& 2). Although verapamil and papaverine were shown to be equiactive in the inhibitions of the tonic components of $\mathrm{ACh}$ and $60 \mathrm{mM} \mathrm{K}$ responses. 

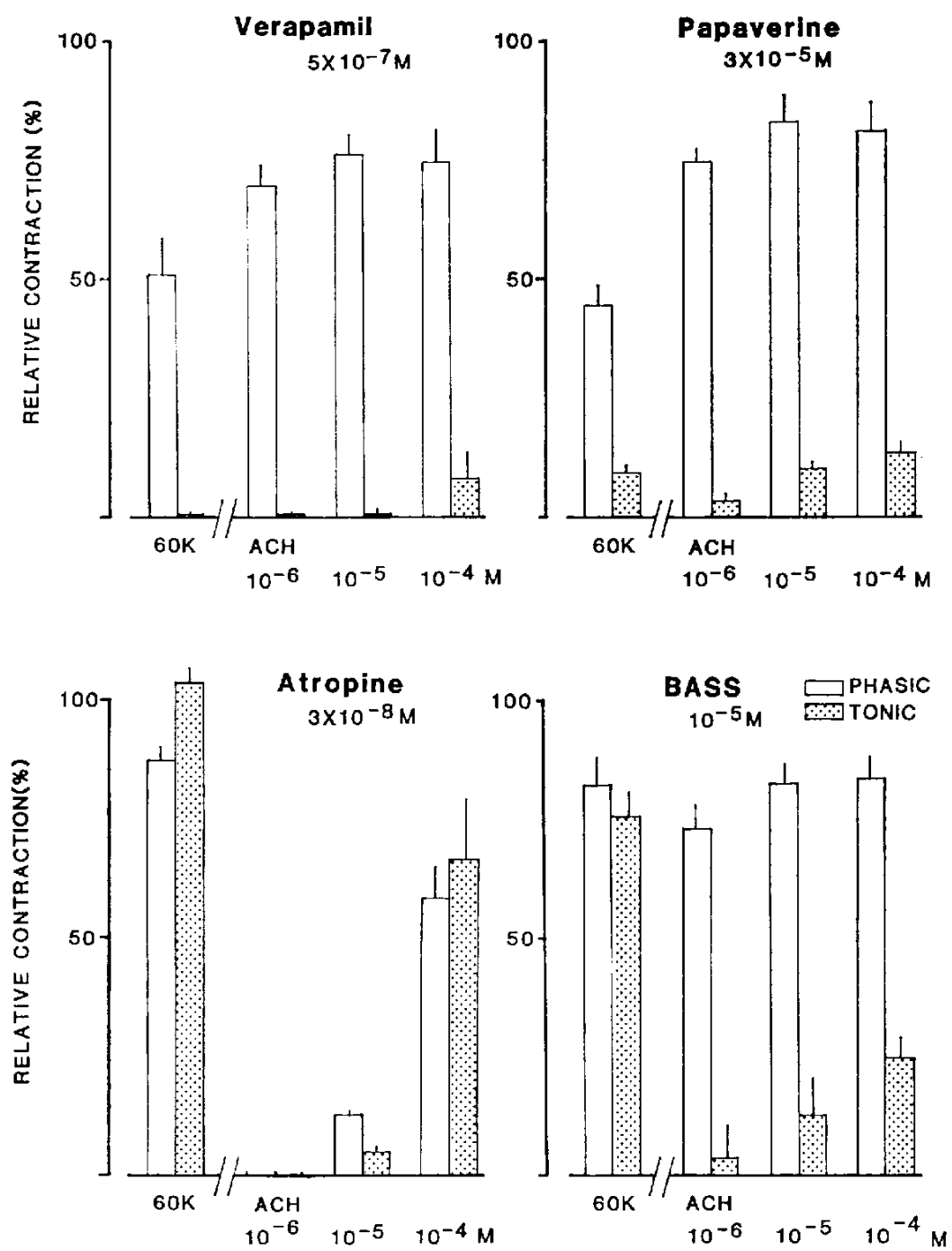

Fig. 2. Effect of verapamil, papaverine, atropine or bassianolide (BASS) on the phasic (opened column) and tonic (dotted column) components of the contraction induced by acetylcholine $\left(10^{-6}-10^{-5} \mathrm{M}\right)$ or $60 \mathrm{mM} \mathrm{K}$ in guinea-pig taenia coli. Ordinate: relative contraction (\%), the maximal size of the phasic or tonic components of a contraction induced by agonist was regarded as $100 \%$. Six muscle strips were employed in each experiment.

BASS displayed a selectivity of inhibition towards the ACh-induced tonic contraction.

Effect of BASS on membrane potential: The membrane potential of the smooth muscle was measured at $32^{\circ} \mathrm{C}$ by the single sucrosegap method. The muscle spontaneously depolarized the membrane accompanying spike discharges as shown in Fig. 3. An application of $10^{-5} \mathrm{M}$ BASS or $10^{-7} \mathrm{M}$ atropine induced a slight hyperpolarization and a disappearance of spike discharges. ACh $\left(10^{-5} \mathrm{M}\right)$ caused a depolarization of approximately $14 \mathrm{mV}$ and increased the frequency of spike discharges. An application of high $\mathrm{K}$ caused depolarization of $12 \mathrm{mV}$ and produced a change in membrane potential 

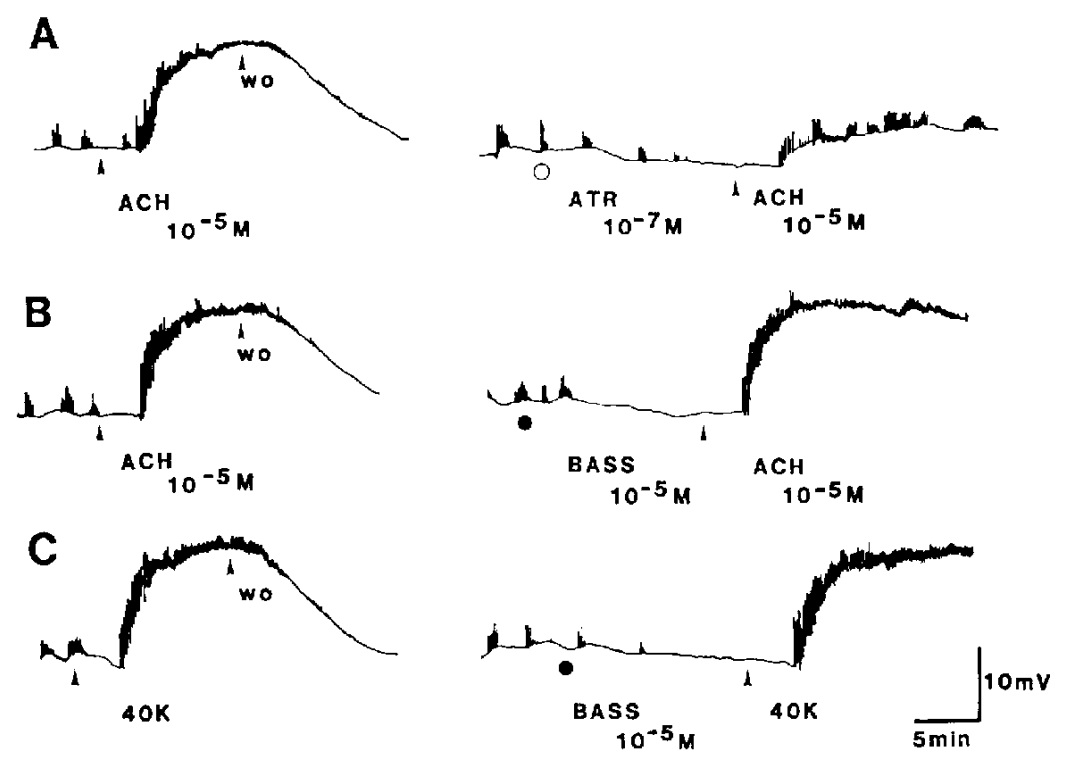

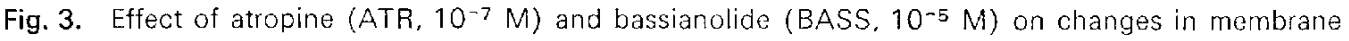
potential by acetylcholine (ACh, $10^{-5} \mathrm{M}$ ) or $40 \mathrm{mM} \mathrm{K}$ in guinea-pig taenia coli. In $\mathrm{A}, \mathrm{B}$ and $\mathrm{C}$. different strips were emploved. In the sucrose-gap apparatus, the flow rate was $6 \mathrm{ml} / \mathrm{min}$. The distance is approximately $30 \mathrm{~cm}$ between the muscle bath and the cock which exchanges the test solution.

similar to that by $\mathrm{ACh}$. Pretreatment with $10^{-7} \mathrm{M}$ atropine decreased the changes by $\mathrm{ACh}$, but did not influence those by high $\mathrm{K}$. On the other hand. pretreatment with BASS $\left(10^{-5} \mathrm{M}\right)$ did not modify the changes in membrane potential by either ACh or high $\mathrm{K}$ (Fig. 3).

Effect of BASS on intracellular $\mathrm{Na}$ and $\mathrm{K}$ contents: In the smooth muscle of taenia coli, intracellular $\mathrm{Na}$ and $\mathrm{K}$ were $5.0 \pm 0.4 \mathrm{mmol} / \mathrm{kg}$ wet $w \mathrm{t}$. and $61.1 \pm 1.0 \mathrm{mmol} / \mathrm{kg}$ wet wt. respectively. ACh or BASS was applied for 30 min to muscle soaked in the medium in the presence or absence of ouabain at a concentration of $2 \times 10^{-5} \mathrm{M}$. ACh $\left(10^{-5} \mathrm{M}\right)$ did not change the values of intracellular $\mathrm{Na}$ and $\mathrm{K}$ contents (Table 1$)$. BASS $\left(10^{-5} \mathrm{M}\right)$ with or without $A C h\left(10^{-5} \mathrm{M}\right)$ also did not modify them. Ouabain $\left(2 \times 10^{-5} \mathrm{M}\right)$ increased intracellular $\mathrm{Na}$ content to $22.7 \pm 1.9 \mathrm{mmol} / \mathrm{kg}$ wet $w t$ and reduced intracellular $K$ content to $39.3 \pm 3.1 \mathrm{mmol} / \mathrm{kg}$ wet wt. ACh $\left(10^{-5} \mathrm{M}\right)$. BASS $\left(10^{-5} \mathrm{M}\right)$ or the combination of both did not influence the ion contents of the muscle treated with ouabain.

Effect of BASS on ${ }^{45} \mathrm{Ca}$ uptake: Amount of ${ }^{45} \mathrm{Ca}$ uptake into the smooth muscle of taenia coli was $27.7 \pm 2.2 \mu \mathrm{mol} / \mathrm{kg}$ wet wt. of tissue for $3 \mathrm{~min}$ or $58.6 \pm 6.1 \mu \mathrm{mol} / \mathrm{kg}$ wet wt. for $6 \mathrm{~min}$ in the normal medium. Sixty $\mathrm{mM}$ $\mathrm{K}$ increased ${ }^{45} \mathrm{Ca}$ uptake to twice that of the control (Table 2). Verapamil at $10^{-6} \mathrm{M}$ decreased the increased ${ }^{45} \mathrm{Ca}$ uptake back to the control level; however. BASS $\left(10^{-5} \mathrm{M}\right)$ did not influence it. On the other hand, $10^{-5} \mathrm{M}$ ACh slightly increased ${ }^{45} \mathrm{Ca}$ uptake of the muscle for $3 \mathrm{~min}$, but did not for $6 \mathrm{~min}$. The result is consistent with the data reported by Triggle and Triggle (10) that cis-2-methyl-4dimethylaminomethyl-1.3-dioxanmethiodide (CD), a typical muscarinic agent at a concentration of $5 \times 10^{-7} \mathrm{M}$, increased ${ }^{45} \mathrm{Ca}$ uptake in ileal longitudinal smooth muscle during the phasic component of $C D$ response, but not during the tonic one. The ${ }^{45} \mathrm{Ca}$ uptake into the muscle treated with $\mathrm{ACh}\left(10^{-5} \mathrm{M}\right)$ was 
Table 1. Changes in celluar $\mathrm{Na}$ and $\mathrm{K}$ contents of guinea-pig taonia coli by acetyicholine, bassianolide and the combination of both, in presence or absence of ouabain

Treatment

Norma!

ACh $\left(10^{-5} \mathrm{M}\right)$

BASS $\left(10^{-5} \mathrm{M}\right)$

ACh $\left(10^{-5} \mathrm{M}\right)+\operatorname{BASS}\left(10^{-5} \mathrm{M}\right)$

Ouabain $\left(2 \times 10^{-5} \mathrm{M}\right)$

ACh $\left(10^{-5} \mathrm{M}\right)+$ Oua $\left(2 \times 10^{-5} \mathrm{M}\right)$

BASS $\left(10^{-5} \mathrm{M}\right)+$ Oua $\left(2 \times 10^{-5} \mathrm{M}\right)$

$\operatorname{ACh}\left(10^{-5} \mathrm{M}\right)+\operatorname{BASS}\left(10^{-5} \mathrm{M}\right)$ + Oua $\left(2 \times 10^{-5} \mathrm{M}\right)$
Collular ion contents ( $\mathrm{mmol} / \mathrm{kg}$ wet wt.)

[Na]

[K] $\mathrm{i}$

$5.0 \pm 0.4$

$61.1 \pm 1.0$

$4.5 \pm 1.3$

$60.8 \pm 2.5$

$5.2 \pm 1.3$

$58.1 \pm 3.7$

$4.2 \pm 0.8$

$62.6 \pm 4.1$

$22.7 \pm 1.9$

$23.9 \pm 1.2$

$19.7 \pm 2.4$

$39.3 \pm 3.1$

$38.7 \pm 3.7$

$40.9 \pm 3.6$

$25.2 \pm 0.4$

$35.9 \pm 1.5$

The muscles were incubated in norma! medium for $1 \mathrm{hr}$, then they were soaked for $30 \mathrm{~min}$ in the medium containing $10^{-5} \mathrm{M} \mathrm{ACh}$ with or without ouabain (Oua, $2 \times 10^{-5} \mathrm{M}$ ). Bassianolide (BASS, $10^{-5} \mathrm{M}$ ) was added $12 \mathrm{~min}$ before the ACh treatment. Ouabain significantly increased [Na] $]_{i}$ and decreased [K] $(P<0.05)$; however, a significant difference was not found between them in the experiment. Each value is the mean of six results \pm S.E.M.

Table 2. Effect of bassianolide. verapamil or atropine on ${ }^{15} \mathrm{Ca}$ uptake into the smooth musclo of guineapig taenia coli treated with $60 \mathrm{mM} \mathrm{K}$ or acetylcholine

\begin{tabular}{|c|c|c|c|}
\hline \multicolumn{2}{|r|}{ Treatment } & \multicolumn{2}{|c|}{${ }^{45} \mathrm{Ca}$ uptake ( $\mu \mathrm{mol} / \mathrm{kg}$ wot $w \mathrm{t}$ ) } \\
\hline & & $3 \mathrm{~min}$ & $6 \mathrm{~min}$ \\
\hline & Normal & $27.7 \pm 2.2$ & $58.6 \pm 6.1$ \\
\hline & $60 \mathrm{~K}$ & $52.7 \pm 4.1^{*}$ & $96.4 \pm 13.0^{*}$ \\
\hline & $60 \mathrm{~K}+\operatorname{Ver}\left(10^{-6} \mathrm{M}\right)$ & $21.8 \pm 1.7^{* *}$ & $51.1 \pm 6.4^{* *}$ \\
\hline & $60 \mathrm{~K}+\operatorname{BASS}\left(10^{-5} \mathrm{M}\right)$ & $48.6 \pm 3.0$ & $94.7 \pm 6.5$ \\
\hline & $\operatorname{ACh}\left(10^{-5} \mathrm{M}\right)$ & $33.8 \pm 1.6^{*}$ & $58.5 \pm 3.2$ \\
\hline & ACh+Ver $\left(10^{-6} \mathrm{M}\right)$ & $24.0 \pm 1.8^{* *}$ & $39.9 \pm 3.1^{* *}$ \\
\hline & $\mathrm{ACh}+\mathrm{Atr}\left(10^{-E} \mathrm{M}\right)$ & $28.6 \pm 1.9$ & $58.3 \pm 7.0$ \\
\hline & ACh+BASS $\left(10^{-5} \mathrm{M}\right)$ & $33.4 \pm 1.4$ & $60.2 \pm 5.0$ \\
\hline
\end{tabular}

The muscles were incubated in normal medium for $2 \mathrm{hr}$. ACh $\left(10^{-5} \mathrm{M}\right)$ or $60 \mathrm{mM} \mathrm{K}$ was simultaneously applied to the muscle with ${ }^{45} \mathrm{CaCl}_{2}$. Bassianolide (BASS, $10^{-5} \mathrm{M}$ ). Verapamil (Ver, 10-8 M) or atropine (Atr, $10^{-6} \mathrm{M}$ ) was added $12 \mathrm{~min}$ before ${ }^{45} \mathrm{Ca}$ loading and kept during the loading. Each value is the mean of six results.tS.E.M. *: Significant difference from the value in normal sol. $(P<0.05)$. *: Significant difference from the value in a solution containing $A C h\left(10^{-5} \mathrm{M}\right)$ or $60 \mathrm{mM} \mathrm{K}(P<0.05)$.

decreased by verapamil $\left(10^{-6} \mathrm{M}\right)$, but it was not decreased by atropine $\left(10^{-6} \mathrm{M}\right)$ or BASS $\left(10^{-5} \mathrm{M}\right)$. The decrease of ${ }^{45} \mathrm{Ca}$ uptake by verapamil below the control level may be caused by blocking the basal $\mathrm{Ca}$ influx of the muscle and/or by an increase of $\mathrm{Ca}$ efflux by $\mathrm{ACh}$ which is not modified by verapamil. Since the cholinergic effect on
Ca efflux of the smooth muscle has not been established, the latter assumption is ambiguous. Since an increase in ${ }^{45} \mathrm{Ca}$ uptake by $\mathrm{ACh}$ for $6 \mathrm{~min}$ was not measured by this method, we could not obtain evidence about whether BASS modifies the Ca uptake during the ACh-induced tonic contraction or not. 


\section{Discussion}

In the previous paper (5), it was reported that BASS inhibited the muscarinic response to $A C h$ but not the nicotinic $\left(N_{2}\right)$ one and that BASS, unlike atropine, did not affect the binding of $A C h$ to the muscarinic receptor of the crude synaptosomal preparation of the brain. In the present paper, atropine which inhibits the binding activity of $\mathrm{ACh}$ to the muscarinic receptor inhibited both the phasic and tonic contractions induced by $\mathrm{ACh}$ in guinea-pig taenia coli. However, BASS, verapamil and papaverine almost completely inhibited the tonic component, but only partly inhibited the phasic one. Moreover. ACh bound to the receptor accelerated action potential discharge and depolarized the membrane with higher concentrations in the smooth muscle of taenia coli $(6,11)$. Atropine inhibited these changes in the membrane potential, but BASS did not. From these data. it seems likely that the inhibition of the AChinduced contraction by BASS is not due to the changes in binding activity of $\mathrm{ACh}$ to the muscarinic receptor or in electrical properties of the cell membrane of smooth muscle.

There are many reports concerning the effect of muscarinic agents on the movement of monovalent cations. Bolton (12) has reviewed that the muscarinic agents increased ${ }^{22} \mathrm{Na}$ influx into and ${ }^{24} \mathrm{~K}$ efflux from intestinal smooth muscle. However, these agents did not influence the $\mathrm{Na}$ level, but they reduced the $K$ level of the muscle. In the present data, ACh, BASS and the combination of both did not change the intracellular $\mathrm{Na}$ and $K$ contents of taenia coli in the presence or absence of ouabain. Although these results were not consistent with the review, the BASS inhibition of the contraction may not be related to the change in the ion contents or movement during the $\mathrm{ACh}$ response.

As Bolton (12) has reviewed, data on the effect of muscarinic agents on Ca fluxes have proved to be ambiguous: Activation of the muscarinic receptor has reported to increase $\mathrm{Ca}$ influx, although other workers have not found this. Some workers have found $\mathrm{Ca}$ efflux to be increased, and others found it unchanged by the muscarinic agent in polarized smooth muscle. However, a current concept has been accepted that the $\mathrm{Ca}$ involved in the tonic component of $\mathrm{ACh}$. induced contraction is derived from an extracellular source. while Ca supporting the phasic component may be derived from a releasable intracellular source. In this study. ${ }^{45} \mathrm{Ca}$ uptake at the 6 th min which corresponds to the tonic response was increased by $60 \mathrm{mM} \mathrm{K}$, but it was not affected by $\mathrm{ACh}$ $\left(10^{-5} \mathrm{M}\right)$. The lack of extra ${ }^{45} \mathrm{Ca}$ uptake during the tonic component of $\mathrm{ACh}$ contraction appears inconsistent with the high dependence of this component upon extracellular $\mathrm{Ca}$. This discrepancy may be explained by a concept that the ${ }^{45} \mathrm{Ca}$ influx specially associated with the mechanical response might not be readily measured by this tracer technique. Accordingly, the present data could not provide substantial evidence indicating an inhibition by BASS or verapamil on the ACh action on $\mathrm{Ca}$ metabolism. However, the fact that BASS did not modify the changes in membrane potential of the muscle by ACh suggests that BASS may not interfere with the electrogenic $\mathrm{Ca}$ influx increased by ACh.

On the other hand, an elevation of external $K$ in medium depolarized the smooth muscle. with an accompanying increase in amplitude and frequency of spike discharge. then induced a contraction. The K-induced contraction also consists of phasic and tonic components. Increase of $\mathrm{Ca}$ uptake during high $\mathrm{K}$ contraction of the guinea-pig intestine has been reported by many investigators $(10$. 13-17). and they have suggested that extracellular $\mathrm{Ca}$ is utilized during the tonic 
component of the contraction and that the phasic contraction is mainly due to a $\mathrm{Ca}$ release from an intracellular store. However. an application of high $K$ appears to release a significant amount of $\mathrm{Ca}$ from a storage site which is different from that derived by a muscarinic agent $(18,19)$. In the present data, verapamil inhibited the tonic contraction and the increased ${ }^{45} \mathrm{Ca}$ uptake in high $\mathrm{K}$ medium. However, BASS slightly inhibited the tension development both in the phasic and tonic phase in a non-selective manner, and BASS did not affect the electrical properties and the increase in the ${ }^{45} \mathrm{Ca}$ uptake into the muscle in high $K$ medium, which seems to be different from verapamil.

In the present data, papaverine as well as verapamil selectively inhibited the tonic component of ACh- or $60 \mathrm{mM} \mathrm{K}$-induced contraction. This effect of papaverine was consistent with that reported in other papers $(20,21)$. Since BASS did not remarkedly inhibit the $60 \mathrm{mM} \mathrm{K}$-induced tonic contraction, the action of BASS seems to be also different from that of papaverine which inhibits phosphodiesterase activity (22-24) or mitochondorial respiration $(25,26)$.

Suzuki and his co-workers $(1,2)$ have reported that BASS is one of the cyclodepsipeptides which has a chemical structure with oxygen atoms on its ring. Such cyclodepsipeptides generally have the properties of an ionophore (27). In the experiments of membrane potential, intracellular $\mathrm{Na}$ and $\mathrm{K}$ contents and ${ }^{45} \mathrm{Ca}$ uptake. BASS did not change the permeability of monovalent or divalent cations through the cell membrane. It is unlikely that BASS has any ionophoric properties towards the cell membrane of smooth muscle.

In summary. BASS selectively inhibited the tonic component of $\mathrm{ACh}$-induced contraction, but slightly inhibited both the phasic and tonic contractions by $60 \mathrm{mM} K$ in a non-selective manner. The mechanism through which BASS inhibits the tonic response to $A C h$ seems to be different from that of verapamil or papaverine which inhibited both the tonic responses to $\mathrm{ACh}$ and $60 \mathrm{mM} \mathrm{K}$, and the mechanism seems not to involve changes in the binding activity of $\mathrm{ACh}$ to the muscarinic receptor, in membrane potential by $\mathrm{ACh}$ and in the contractile machinery of the intestinal smooth muscle.

Acknowledgement: This research was supported in part by a grant from the Japan Tobacco Salt Public Cooperation.

\section{References}

1) Suzuki, A., Kanaoka, M., Isogai, A., Murakoshi, S., Ichinoe, M. and Tamura, S.: Bassianolide. a new insecticidal cyclodepsipeptide from Beauveria bassiana and Verticillium lecanii. Tetrahedron Letters 25, 2167-2170 (1977)

2) Kanaoka, M., Isogai, A., Murakoshi, S., Ichinoe, M., Suzuki, A. and Tamura, S.: Bassianolide a new insecticidal cyclodepsipeptide from Beauveria bassiana and Verticillium lecanii. Agric. Biol. Chem. 42, 629-635 (1978)

3) Nakajyo, S., Shimizu, K., Kometani, A., Kato, K., Kamizaki, J., Isogai, A. and Urakawa, N.: Inhibitory effect of bassianolide. a cyclodepsipeptide on drug-induced contractions of isolated smooth muscle preparations. Japan. J. Pharmacol. 32, 55-64 (1982)

4) Nakajyo, S., Kometani, A., Shimizu, K. and Urakawa, N.: Effect of bassianolide on druginduced contractions of isolated guinea pig aorta. Bull. Nippon Vet. Zootech. Coll. 30, 71 76 (1981) (in Japanese)

5) Nakajyo, S., Shimizu, K., Kometani, A., Yuyama, A., Kobayashi, H., Suzuki, A., Isogai, A. and Urakawa, N.: Effects of bassianolide on muscarinic and nicotinic responses to acetylcholine in various tissue preparations. Bull. Nippon Vet. Zootech. Coll. 31, 40-50 (1982)

6) Bülbring, E. and Burnstock, G.: Membrane potential changes associated with tachyphylaxis and potentiation of the response to stimulating drugs in smooth muscle, Br. J. Pharmacol. 15. 611-624 (1960)

7) van Breemen, C., Aaronson, P. and Loutzenhiser, R.: The influence of $\mathrm{Na}$ in $\mathrm{Ca}$ fluxes in the guinea pig taenia coli. In Vascular Neuroeffector Mechanisms, Edited by Bevan, J.A., Godfraind, T., Maxwell, R.A. and Vanhoutte, P.M., p. 227236, Raven Press, New York (1980) 
8) Karaki, H. and Weiss, G.B.: Alternation in high and low affinity binding of ${ }^{45} \mathrm{Ca}$ in rabbit aorta by norepinephrine and potassium after exposure to lanthanum and low temperature. J. Pharmacol. Exp. Ther. 211, 86-92 (1979)

9) Aaronson, P. and van Breemen, C.: Effects of sodium gradient manipulation upon celfular calcium. ${ }^{45} \mathrm{Ca}$ fluxes and cellular sodium in the guinea pig taenia coli. J. Physiol. (Lond.) 319. 443-461 (1981)

10) Triggle, C.R. and Triggle, D.J.: Arralysis of the action of cations of the lanthanide series on the mechanical response of guinea-pig longitudinal muscle. J. Physiol. (Lond.) 254, 39-54 (1976)

11) Bülbring, E. and Kuriyama, $H$. .: Effect of changes in ionic environment on the action of $\mathrm{ACh}$ and adrenaline on the smooth muscle cells of the guinea pig taenia coli. J. Physiol. (Lond) 166. 59-74 (1963)

12) Bolton, T.B.: Mechanisms of action of transmitters and other substances on smooth muscle. Physiol. Rev. 59, 606-718 (1979)

13) James-Kracke, M.R. and Roufogalis, B.D.: Estimation of the levels of calcium and other electrolytes during various phases of contraction of the longitudinal smooth muscle of the guinea pig ileum. Cell Calcium 1, 37-48 (1980)

14) Mayer, C.J., van Breemen, C. and Casteels, R.: The action of lanthanum and D600 on the calcium exchange in the smooth muscle cells of the guinea-pig taenia coli. Pfluegers Arch. 337, 333-350 (1972)

15) Brading, A.F. and Sneddon, P.: Evidence for multiple sources of calcium for activation of the contractile mechanism of guinea-pig taenia coli on stimulation with carbachol. Br. J. Pharmacol. 70, 229-240 (1980)

16) Urakawa, N. and Holland, W.C.: $\mathrm{Ca}^{15}$ uptake and tissue calcium in $K$ induced phasic and tonic contraction in taenia coli. Am. J. Physiol. 207, 873-876 (1964)

17) Kishimoto, T., Ozaki, H. and Urakawa, N.: A quantitative relationship between cellular $\mathrm{Na}$ accumulation and relaxation produced by ouabain in the depolarized smooth muscle of guinea pig taenia coli. Naunyn Schmiedebergs Arch. Pharmacol. 312, 199-207 (1980)
18) Ohashi, H., Takewaki, T. and Okada, T.: Calcium and the contractile effect of carbachol in the depolarized guinea-pig taenia caecum. Japan. J. Pharmacol. 24, 601-611 (1974)

19) Casteels, R, and Raeymaekers, L.: The action of acetylcholine and catecholamine on an intracellular Ca store in the smooth muscle cells of the guinea-pig taenia coli. J. Physiol. (Lond.) 294, 51-68 (1979)

20) Imai, S. and Takeda, K.: Effect of vasodilators upon the isolated taenia coli of the guinea pig. J. Pharmacol. Exp. Ther. 156, 557-564 (1967)

21) Ferrari, M. and Carpendo, F.: On the mechanism of action of some myolytic agents on depolarized guinea pig taenia coli. Arch. Int. Pharmacodyn. Ther. 174, 223-232 (1968)

22) Kukovetz, W.R., Pöch, G., Wurm, A., Holzmann, S. and Paietta, E.: Effect of phosphodiesterase inhibition on smooth muscle tone. In Ionic Actions on Vascular Smooth Muscle, Edited by Betz. E.. p. 124-131, Springer-Verlag, Berlin (1976)

23) Inatomi, N., Takayanagi, 1. and Takagi, K.: Antiphosphodiesterase activity and nonspecific smooth muscle relaxation tested on intestinal smooth muscles, Japan, J. Pharmacol. 25, 63-69 (1975)

24) Takayanagi, I., Yamashita, H., Manda, T. and Takagi, K.: Calcium ions and relaxation of intestinal smooth muscle induced by papaverine and aspaminol. Japan. J. Pharmacol. 27, 311314 (1977)

25) Tsuda, S., Urakawa, N. and Saito, Y.: The inhibitory effect of papaverine on respirationdependent contracture of guinea pig taenia coli in high- $K$ medium. 1. The relationship between contracture and respiration. Japan. J. Pharmacol. 27, 833-843 (1977)

26) Tsuda, S., Urakawa, N. and Fukami, J.: The inhibitory effect of papaverine on respirationdependent contracture of guinea pig taenia coli in high-K medium. 11 . Inhibition of mitochondrial respiration. Japan. J. Pharmacol. 27, 845-853 (1977)

27) Pressman, B.C.: Biological applications of ionophores. Annu. Rev. Biochem. 45, 501-530 (1976) 